International Journal of Instruction e-ISSN: 1308-1470 • www.e-iji.net

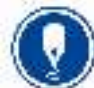

April 2021 • Vol.14, No.2

p-ISSN: 1694-609X

pp. 369-384

Article submission code:

20200113143606

Received: 13/01/2020

Revision: 19/09/2020

Accepted: 11/10/2020

OnlineFirst: 26/01/2021

\title{
Value-Based Digital Storytelling Learning Media to Foster Student Character
}

\section{Didin Saripudin}

Universitas Pendidikan Indonesia, Bandung, Indonesia, kalimaya36@yahoo.co.id

\section{Kokom Komalasari}

Universitas Pendidikan Indonesia, Bandung, Indonesia, kokom@upi.edu

\section{Diana Noor Anggraini}

Universitas Pendidikan Indonesia, Bandung, Indonesia, diana.anggraini@upi.edu

Changes in values of life have caused decline in the quality of global society character, including the character of Indonesian young generation, so it is of necessity to optimize character education through various learning media. This study seeks to develop a value-based digital storytelling media in social studies learning for the formation of student characters. A Research and Development approach was employed with an explorative method used at the model development stage and an experiment method at the model testing stage. Data were collected through observations, interviews, questionnaires, documentation study, and focus group discussions. Qualitative data analysis includes interactive analysis and quantitative data analysis uses a paired sample T-test. Research subject are students of Department of Social Studies at Universitas Pendidikan Indonesia in the ICT Literacy and Learning Media of Social Studies courses. Results reveal that: 1) the concept of value-based digital story telling is a learning medium that exhibits the following characteristics: student engagement through a series of value activities, reflection for deep learning, project-based learning, technology integration into the classroom, and developing values character in action; 2) the making of value-based digital storytelling is carried out through 8 stages: start with an idea, research/explore/learn, write script, storyboard/plan, gather and create images, audio and video, put it all together, share, and reflection and feedback.; 3 ) the use of of value-based digital storytelling media in social studies learning significantly impacts the development of student's character.

Keywords: character, digital storytelling, social studies learning, student, learning media

\section{INTRODUCTION}

Changes in the value of life in today's global society cause a decrease in the quality of character as follows: (1) increased violence among adolescents; (2) worsening use of

Citation: Saripudin, D., Komalasari, K., \& Anggraini, D. N. (2021). Value-Based Digital Storytelling Learning Media to Foster Student Character. International Journal of Instruction, 14(2), 369-384. https://doi.org/10.29333/iji.2021.14221a 
language and words; (3) strong peer group influence in acts of violence; (4) increased self-destructive behavior, such as drugs, alcohol and free sex; (5) blurring of good and bad moral guidelines; (6) decreased work ethic; (7) lower respect for parents and teachers; (8) low sense of responsibility of individuals and citizens; (9) cultivating dishonesty; and (10) mutual suspicion and hatred between people (Lickona, 1991).

The Indonesian nation today is faced with the following critical issues: (1) disorientation and the unfulfilled values of the Pancasila (the nation's five principles) as the nation's view of life; (2) limitations of integrated policy tools in realizing the values of Pancasila; (3) shifting ethical values in the life of the nation and state; (4) waning awareness of national cultural values; (5) the threat of national disintegration; and (6) weakening national independence (Komalasari \& Saripudin, 2018). It is, therefore, necessary to strengthen the nation's character among the younger generation through education at all levels, including universities.

Character education should be integrated into all courses including social studies courses by capitalizing on developing student behaviors. However, the truth is much of social studies learning in Indonesia places more emphasis on instructional effects confined to content mastery or on the cognitive dimension. Consequently, the development of other dimensions (affective and psychomotor) and the acquisition of nurturant effects as a "hidden curriculum" for character formation have not received the ample attention it should. Among the plausible reasons is character development is not yet incorporated in learning as a core activity in higher education (Komalasari \& Saripudin, 2019)

Complicating matters further, the younger generation of Indonesia in the global era is more interested in a foreign culture and less cognizant of the local wisdom of the nation's own culture that develops through stories. Therefore, it is a necessity to promote fairytales/storytelling in social studies learning media for the development and inculcation of character values. Learning media is one of the instrumental components used as intermediaries in the learning process to boost the effectiveness and efficiency in attaining learning objectives (Komalasari \& Saripudin, 2017a; Usman, 2002). In today's digital era, developing learning media based on digital tales or often referred to as digital media storytelling is part and parcel of multimedia learning. The benefits of using digital storytelling include growing creativity, creating a positive classroom atmosphere, and focusing students' attention. Besides, digital storytelling aims to render the learning process more appealing and interactive; improve the quality of student learning; and the teaching and learning process can take place anywhere and anytime (Daryanto, 2010; Engle, 2010).

Digital Storytelling can be a tool for educators in pouring their own stories into a digital product. The use of digital storytelling utilizes the creative talents of educators in developing learning media. Students as prospective educators can participate in creating digital stories and develop communication skills by learning to organize their ideas, pose questions, express opinions, and write narratives. By sharing their work with their friends, students can also gain valuable experiences in criticizing works of their own and others, which can foster their emotional intelligence, collaboration and social learning 
(Robin, 2016). Digital storytelling media developed should be different from other similar multimedia because it embodies the national characters (Komalasari \& Saripudin, 2017b). Therefore, it is of empirical interest to undertake a research and development project on digital value-based storytelling media models for the development of student character.

Based on the above-mentioned background, the research problem in question is how to design a value-based digital storytelling media model in social studies learning to develop student character. In more detail, the research problem is formulated as follows:

1. What is the concept of value-based digital storytelling media in social studies learning to develop student character?

2. How to develop value-based digital storytelling media products in social studies learning to develop student character?

3. How does the use of value-based digital storytelling media influence student character development?

\section{METHOD}

This research was conducted using Borg and Gall's (2003) Research and Development, in which the process was used to develop and validate educational products. In addition to that, this model also aims to discover new knowledge through basic research, or to answer specific questions about practical issues through applied research, which is used to enhance educational practices. In this research, the model was utilized to produce a value-based digital storytelling media model in social studies learning.

\section{Process}

Of ten steps as proposed by Borg and Gall (2003) only step one to five were employed in the present study, namely:

1. Research and information collecting pertained to the issues in question, and preparation for formulating the research framework.

2. Planning that included formulating skills and expertise related to the making of value-based digital storytelling to identify the objectives to be achieved at each stage, and to perform feasibility studies in a limited context.

3. Developing a preliminary form of the product that constituted preparation of supporting components, setting up guidelines and manuals, and assessing the feasibility of supporting tools.

4. Preliminary field testing to generate input from experts and practitioners, and initial product piloting on a limited scale.

5. Main product revision to make improvements to the initial product.

\section{Participants}

The participants of this study were the 2017 Social Studies Education Study Program students enrolled for the ICT Literacy and Social Media Learning Courses in 2019/2020 Odd Semester, with a total of 2 classes (A and B) and a total of 98 students. These participants were chosen so that they could later develop models of value-based digital storytelling media in social studies to be applied in a teaching practicum in school. 


\section{Data Collection Tools}

Data collection techniques used in this study include: (1) participatory observation, (2) documentation study, (3) interview/focus group discussion, and (4) questionnaire. Participatory observation was conducted by the researchers involving themselves in lectures on ICT Literacy and Social Studies Learning Media. Data collected through observation derived from learning resources, namely from the students and the lecturers. Study documentation was used to capture data in written documents that demonstrate a relationship with social studies learning media. Focus Group Discussion was undertaken with the lecturers on learning and learning courses, instructional media, learning evaluation, and social studies teaching planning. The questionnaire was distributed to the students to gauge their perceptions of the application of a value-based digital storytelling media model and its impact on their character development.

\section{Data Analysis}

Data were analyzed qualitatively and quantitatively. Qualitative data analysis was carried out by formulating a conceptual model and developing a value-based digital storytelling media model, while quantitative data analysis was adopted to analyze the results of model validation and the effect of applying the model to the development of student character. Qualitative data analysis was realized through the following steps: (1) conducting data reduction by synthesizing field reports, highlighting the main points relevant to the focus of the research; (2) systematically arranging the data as per specific categories and classifications; (3) presenting the data in tables or figures to further clarify the relationship between the data; (4) conducting a cross-site analysis through in depth data comparison and analysis; and (5) presenting findings, drawing conclusions covering trends and the implications of their application, and recommendations for further development (Fraenkel \& Wallen, 2012). Quantitative data analysis was performed for the data elicited through questionnaires using a different test analysis (gain score) by Wilcoxon's Matched Pairs Test and a t-test by Mann-Whitney U Test (Shadish, et al., 2002). This is because based on the Kolmogorov-Smirnov normality test result of Asymp. Sig. (2 tailed) 0,032<0,05, the data were not normally distributed. Quantitative data analysis was later supplemented with a descriptive quantitative analysis using percentages (Creswell, 2012).

\section{FINDINGS}

The conceptual model of value-based digital storytelling media in social studies learning

Empirically, social studies learning media in the 21 st century through digital storytelling were developed by integrating life values, so that storytelling does not only consist of combining images, sounds, texts, and videos to narrate something that contains learning material, but also embeds meaningful living values presented in a reflective and attractive way by using digitalization. Based on this concept, the proposed model has the following characteristics: 


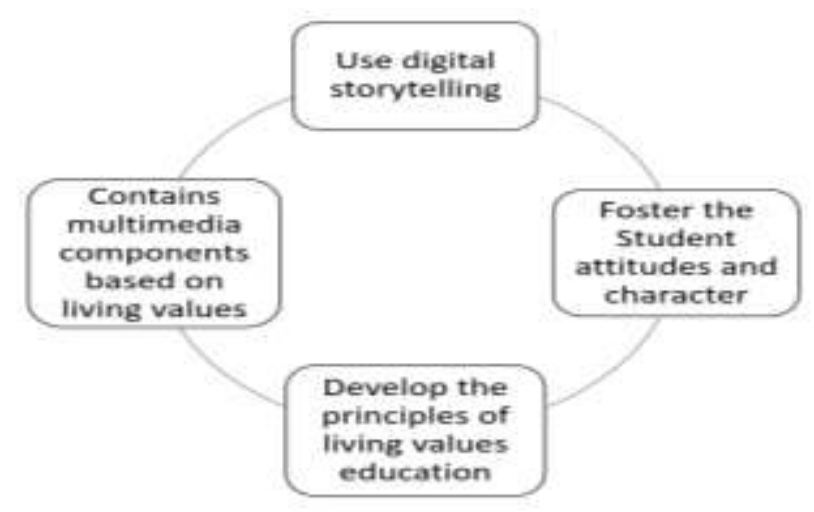

Figure 1

The characteristics of value-based digital storytelling media in social studies learning

a. Digital storytelling is essentially a process of combining images, sounds, texts, and video to tell or describe something (Frazel, 2010; Perry, 2008). In other words, it is a new form of storytelling. In conventional storytelling, a story is written and illustrated on a piece of paper, while in digital one, a story is realized in a video equipped with sounds, images, texts, and animations making the story more appealing. In addition, digital storytelling can cover a variety of topics not limited to classic or traditional stories. The visual products can be anything, and use a variety of available software. The model embraces a digital storytelling property as an active-creative-innovative ICT-based learning media. Digital storytelling is a social studies learning media that fulfills four elements of active-creative-innovative learning (Xu, et al., 2011), namely:

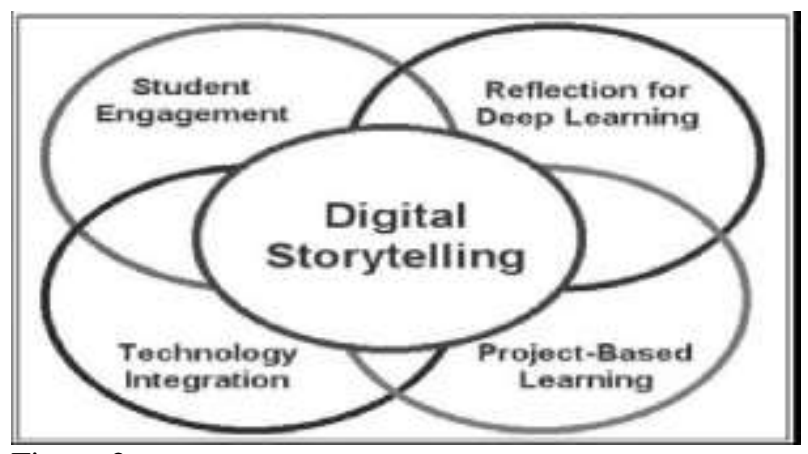

Figure 2

Convergence of Student-centered learning strategies

Based on the above scheme, it is apparent that value-based digital storytelling media must be able to:

1) Actively engage students in learning through a series of activities: the students in ICT Literacy and Social Studies Learning Media courses as the research participants 
were actively involved in lectures, ranging from learning contract and character contract activities, brainstorming in the presentation of material by lecturers, and carrying out value-based digital storytelling media production projects;

2) Exercise reflection for deep learning by carrying out the process of reflection on understanding the subject matter in depth and reflecting the application of values in life. Reflection activities are the core activities of living values education. Lectures begin and end with value reflection activities so that students not only understand social studies material and values, but more importantly internalize and apply values in their daily life (Komalasari \& Sapriya, 2016; Saripudin \& Komalasari, 2016);

3) Adopt a project-based learning where students are facilitated to create a project that manufactures products in the form of value-based digital storytelling presented in class and published on a website. Project-based learning is comprehensive as it taps the ability of students to be fully integrated, namely understanding of concepts, moral values, and norms; identifying and solving problems using critical skills; and generating products to overcome problems using creative and innovative thinking skills;

4) Integrate technology into the classroom in accordance with the demands of $21 \mathrm{st}$ century learning based on the management of information and communication technology. The value-based digital storytelling media model addresses this demand as it incorporates ICT literacy and develops millennial generation capabilities in the Industrial Revolution Era 4.0 commonly referred to as the digital era, the era of big literacy, and the era of disruption.

b. Foster the attitudes and character that every student must embody to support the effectiveness of participation in life. The 2013 curriculum prescribes religious attitudes through KI-1 and social attitudes through KI-2 (covering honesty, discipline, responsibility, politeness, self-confidence, and care) as character contents in social studies learning in the curriculum.

c. Develop the principles of living values education in the making of digital storytelling, which includes: 1) collecting points of reflection; 2) imagining broadly; 3) practicing relaxation and focus; 4) expressing art; 5) developing social skills; 6) raising cognitive awareness about justice; 7) fostering social harmony; and 8) collecting cultural values (Tillman, 2004).

d. Contains multimedia components based on living values including: 1) learning motivation; 2) title of material; 3) menu; 4) core competencies, basic competencies and learning objectives; 5) concept maps; 6) learning material; 7) video reflections rich in values; and 8) quiz (Komalasari \& Rahmat, 2019).

\section{Development of value-based digital storytelling media products in social studies learning}

The results of the focus group discussions with learning multimedia experts and social studies material content experts, as well as practitioners in the field reveal that developing value-based digital storytelling was performed through the following stages:

a. Preparation Stage. At this stage, lecturers and students prepare for the digital storytelling work consisting of: 
1) determining the audience as the target users;

2) determining the type of product to be produced (in the form of a video or a podcast);

3) determining how to present the products (in class or published on a website).

In addition, lecturers also prepare materials and work plans for digital storytelling in the form of:

1) deciding whether the project is to be done individually or in groups;

2) writing a rubric (adapting from Frazel, 2010) to assess the process of preparation, manufacturing and presentation of a product;

3) determining the theme of the project;

4) determining the length of time for the project; and

5) explaining and providing sample products to students.

b. Production Stage. At this stage, students develop digital storytelling by referring to the following 8 stages of Morra (2013).

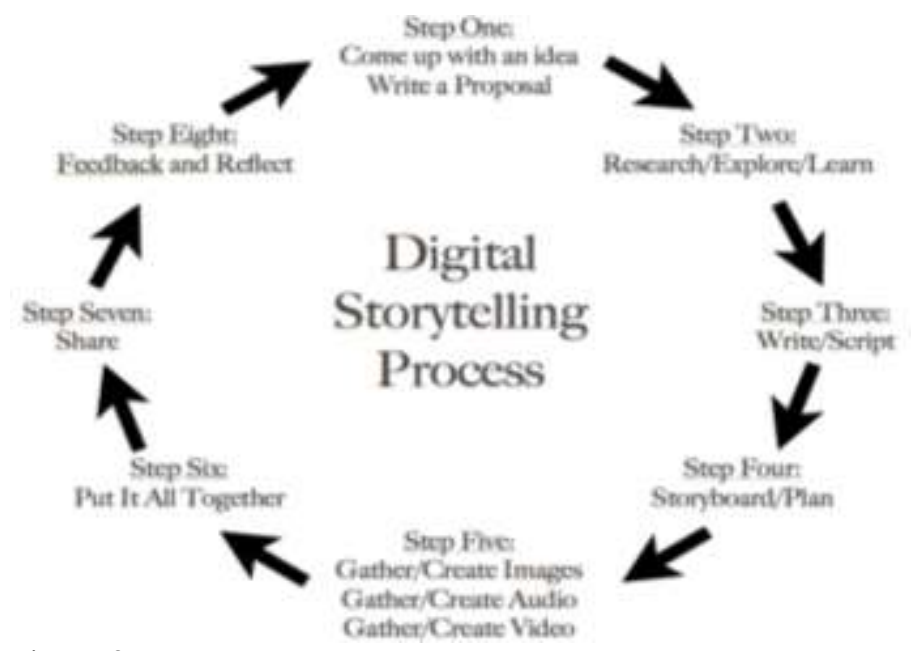

Figure 3

Digital storytelling production process

Based on the picture, the making of Digital Storytelling by students is carried out through 8 stages (Morra, 2013) as follows:

1) Start with an Idea. Like other types of stories, and digital stories should start with an idea. This could be the topic of a lesson, a chapter heading in a textbook, or a question asked in class. The stories might be fictional or non-fictional. Once students come up with an idea, they make it concrete: write a proposal, draw a mind-map, or use any other pre-writing tools.

2) Research/Explore/Learn. Students research, explore or learn about the topic to create a set of information which serves as the basis for the story to be built. During this process, students learn both about validating information and information bias. As organization is crucial, students may utilize mind-mapping to keep track of 
information. Other tools such as outlines, index cards, and online note-taking can be used.

3) Write/Script. Students determine whether they will use a first, second or third person. Students expand word choices by looking up in a dictionary or thesaurus. Students write full research essays or papers before turning them into scripts, so they can become "experts" on the topic.

4) Storyboard/Plan. Students make storyboards as the initial step towards understanding sounds and images. The storyboards function as the blueprint that will assist in making decisions about images, videos and sounds. Simple storyboards constituted images/videos and the script, while more advanced ones might include transitions and background music.

5) Gather and Create Images, Audio and Video. Using the storyboards they made as a guide, students gather - or create - images, audio and video. Their choice will influence and set the tone for their digital story. Visual hierarchy, tone, and illustration, as part of the concepts, can also be introduced. At this junction, discussions on copyright, fair use, and creative commons can be done. Students may record themselves reading their scripts at this stage.

6) Put It All Together. Students revisit and revise their storyboards. They blend images, create unique transitions between video clips, amd incorporate music or sound effects. At this stage, a rubric is provided so students understand what is expected for a completed project.

7) Share. Students share online digital storytelling projects they have made on youtube or vimeo. Lecturers then look for ways to share student projects with a wider audience to increase student motivation and make it the best possible work that they can do.

8) Reflection and Feedback. Lecturers allow students to do reflection and give feedback. What did I learn? How can I do better next time? Students learn how to reflect on their work and provide constructive feedback to their peers. Blogs, wiki discussion boards, and student response systems or polling are among the tools students can utilize.

At this junction, lecturers monitor and evaluate the manufacturing process including the content of each product draft based on the rubric adapted from Frazel (2010).

c. Presentation Stage. At this stage, students presented their digital story products directly to the audience (lecturers and classmates) and entertained questions as feedback. In addition or alternatively, students may also present their products indirectly on a CD or DVD or upload the files onto a website, e.g. Youtube.

Value-based digital storytelling products in social studies learning that have been produced are validated by experts. Validation is carried out by media experts and content / material experts, the results can be seen in the following table. 
Table 1

The results of expert validation $(\mathrm{N}=6)$

\begin{tabular}{lllll}
\hline No & Assessed Aspects & Less than satisfactory $(\%)$ & Satisfactory $(\%)$ & Good (\%) \\
\hline 1. & Curriculum and Instructional Design & 04.30 & 10.04 & 86.66 \\
\hline 2. & Material Content & 03.45 & 05.55 & 92.00 \\
\hline 3. & Communication & 04.78 & 08.56 & 86.66 \\
\hline 4. & Computer Capacity & 08.00 & 12.00 & 80.00 \\
\hline 5. & Creativity & 05.22 & 06.78 & 88.00 \\
\hline 6 & Conformity with living values & 08.24 & 18.43 & 73.33 \\
\hline 7 & Display Design & 09.12 & 10.88 & 80.00 \\
\hline 8 & Interactivity & 09.87 & 10.13 & 80.00 \\
\hline & & 06.62 & 08.76 & 84.62 \\
\hline
\end{tabular}

Based on the two tables of the validation of the value-based digital storytelling media model in social studies learning, it can be concluded that the media is perceived good. The aspects deemed to have been good are the aspects of material content, creativity, communication, and curriculum and design. The aspects considered satisfactory are computer capacity, display design and interactivity. Meanwhile, what is assumed weak or less than satisfactory is conformity with the value of life. Thus, further exploration and clarification of living values need improvement.

The effect of the application of value-based digital storytelling learning media on student character development

The test results of paired samples t-test reveal Sig. (2-tailed) is $0.000<\mathrm{a}(0.05)$. It signifies that there is a statistical difference in the development of students' character from the beginning of the measurement (pretest) to the final measurement (posttest) in both the experimental and control classes. The mean scores of the pretest and posttest of the experimental class were greater than those of the control class.

The gained scores in the control and experiment clasess indicate significant statistical differences in students' character formation between the class employing digital story telling media (1.02 ) with that with conventional learning media (0.28). Students' character formation in the class that integrates digital story telling media in social studies learning was greater than its counterpart. The average scores of pretest-posttest and gained score control and experiment classes are presented in Table 2.

Table 2

$\underline{\text { Average scores of the pretest - posttest and gained score control and experiment classes }}$

\begin{tabular}{lllllll}
\hline Classroom Data & Mean & $\begin{array}{l}\text { Standard of } \\
\text { Deviation }\end{array}$ & Variants & Gain & $\begin{array}{l}\text { N } \\
\text { Gain }\end{array}$ & AsympSig \\
\hline Control Pre-test & 54.45 & 5.421 & 30.623 & 1.30 & 0.28 & \\
\hline Control Post-test & 67.73 & 4.532 & $2 ., 482$ & & & \\
\cline { 1 - 3 } Experiment Pre-test & 55.07 & 5.301 & 29.149 & \multirow{2}{*}{4.29} & 1.02 & 0.000 \\
\cline { 1 - 4 } & Experiment Post-test & 102.11 & 8.144 & 66.321 & & \\
\hline
\end{tabular}

The results of descriptive quantitative data analysis, the characters to be inculcated through digital storytelling media on the basis of 2013 curriculum constitute religiosity, 
honesty, discipline, responsibility, courtesy, self-confidence, and care. The description of these characters and how they were implemented can be seen in Table 3.

Table 3

Student characters

\begin{tabular}{|c|c|c|c|c|c|}
\hline \multirow[t]{2}{*}{ No } & \multirow[t]{2}{*}{ Character } & \multirow[t]{2}{*}{ Indicator of implementation } & \multicolumn{3}{|c|}{ Scores } \\
\hline & & & good & satisfactory & $\begin{array}{l}\text { less than } \\
\text { satisfactory }\end{array}$ \\
\hline \multirow[t]{6}{*}{1} & \multirow[t]{6}{*}{ Religiousity } & praying before and after performing an activity & 87.54 & 10.22 & 2.34 \\
\hline & & $\begin{array}{l}\text { performing religious duties based on respective } \\
\text { religions }\end{array}$ & 85.76 & 11.23 & 3.01 \\
\hline & & $\begin{array}{l}\text { being grateful for God's blessings } \\
\text { maintaining good relationship with fellow human }\end{array}$ & 86.01 & 10.78 & 3.21 \\
\hline & & beings & 82.45 & 13.61 & 3.94 \\
\hline & & $\begin{array}{l}\text { respecting others who are performing their religious } \\
\text { duties }\end{array}$ & 85.23 & 12.02 & 2.75 \\
\hline & & & 85.40 & 11.77 & 2.83 \\
\hline \multirow[t]{6}{*}{2} & \multirow[t]{6}{*}{ honesty } & not cheating in exams & 65.72 & 20.54 & 13.74 \\
\hline & & not plagiarizing in doing tasks & 66.54 & 20.02 & 13.44 \\
\hline & & expressing feelings as they are & 70.24 & 21.87 & 7.89 \\
\hline & & writing a report factually & 74.26 & 16.04 & 9.7 \\
\hline & & admitting mistakes & 70.92 & 22.43 & 6.65 \\
\hline & & & 69.54 & 20.18 & 10.28 \\
\hline \multirow[t]{4}{*}{3} & \multirow[t]{4}{*}{ discipline } & being punctual & 68.45 & 20.34 & 12.21 \\
\hline & & adhering to school rules & 69.72 & 18.02 & 12.26 \\
\hline & & collecting tasks according to assigned time & 70.02 & 19.92 & 10.06 \\
\hline & & & 69.40 & 19.43 & 11.17 \\
\hline \multirow[t]{6}{*}{4} & \multirow[t]{6}{*}{ responsibility } & performing individual tasks well & 76.89 & 20.06 & 4.05 \\
\hline & & taking the risk of the action & 74.91 & 21.03 & 4.06 \\
\hline & & not blaming/accusing others without proof & 80.01 & 14.75 & 5.24 \\
\hline & & acknowledging and apologizing for any wrongdoing & 72.08 & 22.04 & 5.88 \\
\hline & & keeping promise & 76.76 & 21.01 & 2.23 \\
\hline & & & 76.13 & 19.78 & 4.09 \\
\hline \multirow[t]{6}{*}{5} & \multirow[t]{6}{*}{ courtesy } & respecting older people & 86.92 & 10.06 & 4.02 \\
\hline & & $\begin{array}{l}\text { saying no dirty, rude, and obscene words } \\
\text { greeting others and smiling }\end{array}$ & 84.22 & 9.98 & 5.08 \\
\hline & & thanking after receiving someone else's help & 87.19 & 10.65 & 2.16 \\
\hline & & asking a permission when going into someone else's & 85.08 & 11.32 & 3.60 \\
\hline & & room or using someone else's belongings & 87.52 & 8.79 & 3.69 \\
\hline & & & 86.19 & 10.16 & 3.65 \\
\hline \multirow[t]{6}{*}{6} & \multirow{6}{*}{$\begin{array}{l}\text { self } \\
\text { confidence }\end{array}$} & giving opinions without hesitation & 76.23 & 12.34 & 11.43 \\
\hline & & being able to make right decisions & 77.21 & 15.56 & 7.23 \\
\hline & & being not easily discouraged & 74.89 & 13.92 & 11.19 \\
\hline & & daring to give a presentation in front of the class & 75.90 & 16.02 & 8.08 \\
\hline & & daring to argue, ask, or answer questions & 76.78 & 14.43 & 8.79 \\
\hline & & & 77.80 & 14.45 & 7.75 \\
\hline \multirow[t]{6}{*}{7.} & \multirow[t]{6}{*}{ care } & helping people in need & 85.73 & 9.06 & 5.21 \\
\hline & & not doing activities that interfere with other people & 86.23 & 8.27 & 5.50 \\
\hline & & maintaining the school environment & 84.64 & 10.23 & 5.13 \\
\hline & & throwing garbage in its place & 87.01 & 9.06 & 3.93 \\
\hline & & turning off water faucets and lights when not in use & 83.98 & 11.97 & 4.05 \\
\hline & & & 85.52 & 9.72 & 4.76 \\
\hline \multicolumn{3}{|c|}{ Average Scores } & 78.56 & 14.98 & 6.46 \\
\hline
\end{tabular}

Based on the table above, most of the students' characters are in the good category $(78.56 \%)$, satisfactory $(14.98 \%)$, and less than satisfactory (6.46). The characters that have been well applied are religiousity, courtesy and care, while those that are quite well 
applied are the character of responsibility and self-confidence. Meanwhile, the characters that need to be continually developed through habituation are honesty and discipline.

\section{DISCUSSION}

The results of the research as stated above entail a number of key research findings that can be accounted for under various theories and views as follows:

First, digital stories are like a short and personal movie, utilizing images, videos and narratives to tell a simple story by combining several skills namely speaking skills, writing skills, listening skills and the skills to operate programs that utilize ICT development (Maddin, 2011; Robin, 2016). Digital storytelling in the context of the present paper is supported by numerous characteristics including: 1) actively engaging students in learning through a series of activities, ranging from learning contract activities and character contracts, brainstorming in presenting material by lecturers, and carrying out the project of creating value-based digital storytelling media; 2) reflecting for deeper learning, understanding subject matter in depth and the application of values in life; 3) using project-based learning where students are facilitated to create a project that produces products in the form of value-based digital storytelling presented in class and published online; 4) integrating technology into the classroom under the demands of 21 st century learning based on the management of information and communication technology; and 5) developing attitudes and character that every student must demonstrate to support the effectiveness of participation in life.

Second, digital story telling shapes stories that involve a 'dialogical' approach between stories of past and present experiences for public consumption (Meadows, 2003; Taylor, 2006). Based on the observations, the application of digital story telling media in learning media lectures uses social work practice methods as a participatory approach between students. The students used digital narration in each story developed as a useful tool as a social worker or practitioner. Being in contact with social work practices can help students to manage important moments in their lives such as social life; character crises related to moral conflicts, values and beliefs; and social phenomena in Indonesia imbued with strong meanings (Freeman, 2011; Lenette, et al., 2015; White, 2003)

Third, based on the results of the validation, digital storytelling media in ICT literacy lectures and social studies learning were very well used. This is because the components of digital story telling were accommodated in the model so that the media could be effectively used in the learning process. Among such components are point of view, dramatic questions, emotional content, voice, soundtrack, economy, and pacing.

1) Point of view contains initial information about the contents of the story that presents what information students will get through the media. This initial information can be in the form of the title of the story;

2) Dramatic question contains questions that will direct students in obtaining information;

3) Emotional content contains the delivery of varied information so as not to make students bored; 
4) Voice contains the voice to convey information that must be delivered based on the contents of the story;

5) Soundtrack contains supporting music that can support the delivery of information processes to be more interesting;

6) Economy contains appropriate time management so that the information delivered perfectly aligns with the target; and

7) Pacing contains the time slot in the process of delivering information (Engle, 2010).

Fourth, the application of digital storytelling media in ICT literacy and social studies learning media subjects was classified as 'Good'. This can be attributed to the existence of a tight combination of hardware and software technology that holistically meshes with the classroom atmosphere and centers on acquiring the skills needed for their current needs and their future work (Riesland, 2005). Burmark (2004) in his research found that the activities of integrating visuals with texts profoundly improve and accelerate student understanding, and digital story telling is an excellent technological tool for collecting, creating, analyzing, and combining visuals with texts. Lecturers facilitate students not only to create their own stories, but also to have discussions of topics presented in a story and help render abstract or conceptual contents easier to grasp. The story is put into a digital variation that is rich in multimedia and can serve as a supporting means in appreciating their stories.

Fifth, the application of digital story telling media in ICT literacy and ICT learning media of social studies in character development of students is adjudged as 'Good'. The application of this media develops the character of students including religiosity, honesty, discipline, responsibility, courtesy, self-confidence, and care. Character becomes one of the 21 st century competencies that students must have, and digital learning media supports the achievement of information technology competence in the 21 st century ( Trilling and Fadel, 2009). This is influenced by what the groups of students tell in the form of digital stories that are funny, sad, informative, and entertaining. The principle is that messages are to be conveyed appropriately, so that the goal of instilling character contained in the story messages can be effectively attained. According to research conducted by Small \& Vorgan (2008) in his book entitled IBrain, information read through the screen would last longer in memory. In addition, reading through the screen will increase the process of connecting neurons in the brain. Benmayor (2008) argues that digital storytelling empowers students in a range of ways intellectually, culturally and creatively. They are asked to tell stories using narration and visual texts that suit the concepts, theories, and reality of their stories. This is done to explicate what understanding or insight they extract about their own identity, cultural values and living values (Saripudin, \& Komalasari, 2015; Saripudin \& Komalasari, 2016).

Sixth, empirically the results of this research exhibit significant differences in the development of students' character formation between the class that uses digital story telling media in social studies learning $(1,02)$ with the class that uses conventional learning media $(0.28)$. Students' character formation in the class that integrates digital story telling media in social studies learning is higher than the other one that uses 
conventional learning media. This is influenced by students' interpretations of their reality. Storytelling through digitalization allows students to "evaluate the reality around them and produce their own interpretations about it". It also contributes to the acquisition of skills and knowledge-based interactions of students with the physical world such as social skills, cultural skills and character development (Gregori-Signes', 2014; Lickona, 1991). Smeda et al. (2014) found that the ability of digital storytelling to personalize student learning experiences supports student diversity, increases student self-confidence and enhances their social and psychological skills.

The foremost benefit is students create their own digital stories, individually or as members of small groups. This creative work provides them with a solid foundation in education (Brown et al., 2005; Jakes \& Brennan, 2006). Regardless of the specific terms used, these skills are believed as a combination of: 1) digital literacy (the ability to communicate with an evolving community to discuss problems, gather information, and seek help); 2) global literacy (the ability to read, interpret, respond to, and contextualize messages from a global perspective); 3) technological literacy (the ability to use computers and other technologies to improve learning, productivity, and performance); 4) visual literacy (the ability to understand, produce, and communicate through visual images); and 5) information literacy (the ability to find, evaluate, and synthesize information). In general, the lecturers believe that digital media in a classroom can enhance student digital literacy and foster new skills (Abdulkarim et al., 2018).

\section{CONCLUSION}

Value-based digital story telling media are characterized by the following characteristics: a) student engagement; b) reflection for deep learning; c) project-based learning, d) technology integration into the classroom; and e) developing the attitudes and character that every student must possess to support the effectiveness of participation in life. The application of value-based digital story telling media in social studies significantly and positively impacts on the development of student characters. The student characters that are dominantly developed through this learning media are religiousity, courtesy, care, responsibility and self-confidence. The implication is that digital storytelling media can be used as alternative learning media to develop student character in Indonesia and can be applied internationally because it is in line with $21 \mathrm{st}$ century learning

\section{ACKNOWLEDGEMENT}

The resear ch is a grant from Universitas Pendidikan Indonesia. The author would like to express sincere appreciation for all the support provided.

\section{REFERENCES}

Abdulkarim, A., Ratmaningsih, N., \& Anggraini, D. N. (2018). Developing Civicpedia as a Civic Education E-Learning Media To Improve Students' Information Literacy. Journal of Social Studies Education Research, 9(3), 45-61.

Benmayor, R. (2008). Digital Storytelling as A Signature Pedagogy for The New Humanities. Arts and Humanities in Higher Education 7(2), 188-204. 
Borg, W. R., \& Gall, M.D., (2003). Educational Research: An Introduction $\left(7^{\text {th }}\right.$ ed). Boston: Ally \& Bacon.

Burmark, L. (2004). Visual Presentations That Prompt, Flash \& Transform. Media and Methods, 40(6), 4-5.

Brown, J., Bryan, J., \& Brown, T. (2005). Twentyfirst century literacy and technology in K-8 Classrooms. Innovate, 1(3). Retrieved March 20, 2006, from http://www.innovateonline.info/index. php?view=article\&id=17

Creswell, J.W. (2012). Educational Research: Planning, Conducting, and Evaluating Quantitative and Qualitative Research. Boston: Pearson Education, Inc.

Daryanto. (2010). Media Pembelajaran. Jogjakarta : Gava Media.

Engle, A. n.d. (2010). Digital Story Telling: Everyone Has a Story To Tell. Retrieved March 11, 2015, from http://www.todaysteacher,com.

Fraenkel, J. \& Wallen, N. (2012). How to Design and Evaluate Research in Education. New York: McGraw-Hill Inc

Frazel, M. (2010). Digital Storytelling Guide for Educators. Oregon: International Society for Technology in Education.

Freeman, E. M. (2011). Narrative Approaches in Social Work: A Life Span, Culturally Centered, Strengths Perspective, Springfield, Charles C Thomas.

Gregori-Signes, C. (2014). Digital Storytelling and Multimodal Literacy in Education. Porta Linguarum, 22, 237-250.

Jakes, D. S., \& Brennan, J. (2006). Capturing Stories, Capturing Lives: An Introduction to Digital Storytelling. Retrieved May 2, 2007, from http://www. jakesonline.org/dstory_ice.pdf

Komalasari, K \& Sapriya. (2016). Living Values Education in Teaching Materials to Develop Students' Civic Disposition, The New Educational Review, 44(2), 107-124. DOI: 10.15804/tner.2016.44. 2.09.

Komalasari, K \& Saripudin, D. (2017a). A Model of Living Values Education-based Civic Education Textbooks in Indonesia. The New Educational Review, 47(1). DOI: 10.15804/tner.2017.47.1.11

Komalasari, K. \& Saripudin, D. (2017b). Value-Based Interactive Multimedia Development through Integrated Practice for the Formation of Students' Character, Tourkish Online Journal of Educational Technology, 16(4), 179-186.

Komalasari, K \& Saripudin, D. (2018). The Influence of Living Values EducationBased Civic Education Textbook on Student's Character Formation, International Journal of Instruction, 11(1), 395-410. DOI: 10.12973/iji.2018.11127a 
Komalasari, K \& Rahmat. (2019). Living Values Based Interactive Multimedia in Civic Education Learning, International Journal of Instruction, 12(1), 113-126. DOI: 10.29333/iji.2019.1218a.

Komalasari, K \& Saripudin, D. (2019). Service Learning Model in Social Studies to Foster Student Social Care. The New Educational Review, 56(2), 204-214. DOI: 10.15804/tner.2019.56.2.17.

Lenette, C, Cox, L, \& Brough, M. (2015) Digital storytelling as a social work tool : learning from ethnographic research with women from refugee backgrounds. British Journal of Social Work, 45(3), 988-1005. This file was downloaded from: https://eprints.qut.edu.au/65104/

Lickona. (1991). Educating for Character (How Our Schools Can Teach Respect and Responsibility). New York: Bantam Books.

Maddin, E. (2011). Using TPCK with Digital Story Telling to Investigate Contemporary Issues in Educational Technology. Journal of Instructional Pedagogies, 2-6.

Meadows, D. (2003). 'Digital storytelling: Research-based practice in new media'. Visual Communication, 2(2), 189-193, doi:10.1177/1470357203002002004.

Morra, S. (2013). 8 Steps To Great Digital Storytelling. Retrieved December 08, 2014. From https://samanthamorra.com/2013/06/05/edudemic-article-on-digital-storytelling/

Perry, K. H. (2008) 'From storytelling to writing: Transforming literacy practices among Sudanese refugees', Journal of Literacy Research, 40(10), 899-912.

Riesland, E. (2005). Visual literacy in the classroom. New horizons for learning. Retrieved May 18, 2007, from http://www.newhorizons.org/strategies/ literacy/riesland.htm

Robin, B. R. (2016). The Power of Digital Storytelling to Support Teaching and Learning. Digital Education Review, 30, 17-29.

Saripudin, D. \& Komalasari, K. (2015). Living Values Education in School's Habituation Program and Its Effect on Student's Character. The New Educational Review, 39(1), 51-62.

Saripudin, D. \& Komalasari, K. (2016). Culture-based Contextual Social Studies Learning for Development of Social and Cultural Values of Junior High School Students. The Social Sciences, 11, 5726-5731. DOI: 10.3923/sscience. 2016.5726.5731.

Shadish, W. R., Cook, T. D. \& Campbell, D. T. (2002). Experimental and QuasiExperimental Design for Generalized Causal Inference. Boston: Houghton Mifflin Company.

Small, G \& Vorgan. (2008). iBrain: Surviving the Technological Alteration of the Mondern Mind. HarperColins. 
Smeda, N., Dakich, E., \& Sharda, N. (2014). The effectiveness of digital storytelling in the classrooms: A comprehensive study. Smart Learning Environments, 1(1), 1-21. doi: 10.1186/s40561-014-0006-3

Taylor, C. (2006) 'Narrating significant experience: Reflective accounts and the production of (self) knowledge', British Journal of Social Work, 36(2), 189-206.

Tillman, D. (2004). Living Values: Activities for Children Ages 8-14. Jakarta: PT Gramedia Widiasarana Indonesia.

Trilling, B. \& Fadel, C. (2009). 21st Century Skills: Learning for Life in Our Times, John Wiley \& Sons, 978-0-47055362-6.

Usman, N. (2002). Konteks Implementasi Berbasis Kurikulum. Jakarta: PT. Raja Grafindo Persada.

White, M. (2003) 'Narrative practice and community assignments', The International Journal of Narrative Therapy and Community Work, 2, 20-55.

Xu, Y., Park, H., \& Baek, Y. (2011). A new approach toward digital storytelling: An activity focused on writing self-efficacy in a virtual learning environment. Journal of educational technology \& society, 14(4), 181-191. 